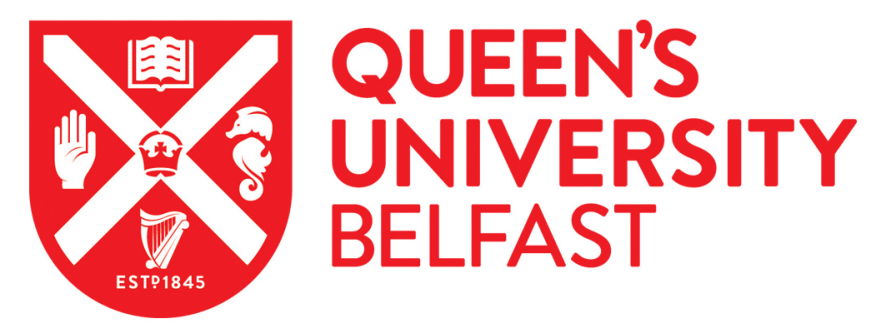

\title{
A Viking Ship Graffito from Kilclief, County Down, Ireland
}

McCormick, F., \& Kastholm, O. (2016). A Viking Ship Graffito from Kilclief, County Down, Ireland. The International Journal of Nautical Archaeology. https://doi.org/10.1111/1095-9270.12207

\section{Published in:}

The International Journal of Nautical Archaeology

\section{Document Version:}

Peer reviewed version

\section{Queen's University Belfast - Research Portal:}

Link to publication record in Queen's University Belfast Research Portal

\begin{abstract}
Publisher rights
(c) 2016 The Authors. This is the peer reviewed version of the following article: McCormick, F. and Kastholm, O. (2016), A Viking Ship Graffito from Kilclief, County Down, Ireland. International Journal of Nautical Archaeology. which has been published in final form at

http://onlinelibrary.wiley.com/wol1/doi/10.1111/1095-9270.12207/abstract This article may be used for non-commercial purposes in accordance with Wiley Terms and Conditions for Self-Archiving.
\end{abstract}

\section{General rights}

Copyright for the publications made accessible via the Queen's University Belfast Research Portal is retained by the author(s) and / or other copyright owners and it is a condition of accessing these publications that users recognise and abide by the legal requirements associated with these rights.

Take down policy

The Research Portal is Queen's institutional repository that provides access to Queen's research output. Every effort has been made to ensure that content in the Research Portal does not infringe any person's rights, or applicable UK laws. If you discover content in the Research Portal that you believe breaches copyright or violates any law, please contact openaccess@qub.ac.uk. 


\section{A Viking Ship Graffito from Kilclief, County Down, Ireland}

<running head: A Viking Ship Graffito from Kilclief, Ireland>

Finbar McCormick

School of Geography, Archaeology and Palaeoecology, Queen’s University Belfast, Ireland. f.mccormick@qub.ac.uk

Ole Kastholm

ROMU, Research \& Exhibitions Department, Roskilde, Denmark. olekast@romu.dk

Deep ploughing near Kilclief, County Down near the site of an early monastery disturbed a large quantity of buried stones. One of these displayed a Viking-type ship with a furled sail. Decorative artwork on the stone suggests an 11th-century date. The ship displays close similarities to Viking ship graffiti in Viking Dublin and in the Scandinavian homelands. This article describes the decorated stone and suggests that it represents an Irish ship constructed in the Viking style. Documentary sources indicate that ships were being granted by an Irish over-king to a local king of this area at this time.

Keywords: Ship graffiti, Ireland, Viking, Medieval, stepped stem, square sail.

Kilclief (Fig 1.) is the site of an early medieval monastery named Cell-cleithe (the church of the hurdles). No upstanding remains of the monastery survive but presumably it was centred on the graveyard now occupied by a small 19th-century Church of Ireland church. A series of Anglo-Norman grave slabs are preserved within this building (Jope, 1966: 304). John Colgan, the 17th-century compiler of the lives of early Irish saints, argued that Kilclief was founded by St Patrick and its first minsters were Eugenius and Niellus (Reeves, 1847: 38). Ó’Rian (2011: 153), however, thinks it more likely that the monastery was founded by St Caolán (alias Machaoi), a disciple of Patrick and founder of the monastery at Nendrum on Strangford Lough, who is recorded as having died in AD 497 or 499. Kilclief lies at a strategic point on the Narrows channel, which allows access to Strangford Lough. This, no doubt, was why the site was later chosen for the location of a motte and tower-house in later medieval times (Jope, 1966: 194, 233-234). There is also a small sandy bay present at the site that would have facilitated the landing of ships. 
Strangford Lough, Lough Cuan in the early sources, was a focus of Viking activity during the 9th and 10th centuries. Dun Lethglaise (Downpatrick) was plundered by the 'heathens' (Vikings) as early as 825 according to Annals of Ulster (AU; Hennessy, 1887'). There was certainly a Viking base on Strangford Lough by the early 10th century as the same annals record in 926 that Dunseverick (Dún Sobairche), Co. Antrim, was sacked by the 'foreigners of Lough Cuan'. The same annals record that 'their island' was taken from the foreigners after the sacking of Downpatrick in 942. Kilclief, located on the shore of the Narrows, would have been particularly susceptible to Viking attack. The Annals of the four Masters (O’Donovan, 1856) records in 935 that 'Cill-Cleithe [Kilclief] was plundered by the son of Barith and the church was burned and a great prey was carried off'. The term doimhliac was used for the church in this record, implying that it was built of stone. Kilclief, along with Inch near Downpatrick, was again attacked by the Dublin Viking named Sitric in 1001, and prisoners from both monasteries were taken away. After this there is no further record of raiding at Kilclief. According to Reeves (1847: 38) Kilclief was annexed to the see lands of Down in 1034.

Deep ploughing in 2005 of a field near the tower-house at Kilclief, County Down brought a quantity of large stones to the surface (Fig. 1). Some of these were later used for cladding a modern house about $3.5 \mathrm{~km}$ south-west of the find-spot and included the carved stone described in this article. This stone (Figs 2-4) measures $63 \times 61 \mathrm{~cm}$ and is a metamorphosed mudstone or slate, interrupted by natural tectonic fissures. It is extremely hard stone and the carving has remained virtually unweathered since it was made. The graffiti comprises a ship and series of unsophisticated decorative designs, similar to those encountered on motif pieces (O’Meadhra, 1979), and some crudely executed zoomorphic figures (Figs 2-3). The stone also displayed several areas of incidental scratch marks, many of which post date the carving (Fig 3). These are omitted from the drawing (Fig. 4).

\section{The ship}

The most striking feature on the Kilclief stone is the engraved ship. It is $36 \mathrm{~cm}$ long and 35 cm high. The ship is characterized by high sweeping ends, a single mast and a lowered sail. The latter gives the notion of a moored or anchored vessel. According to the rigging the ship's bow is to the left. Although the engraving is rather crude, it contains some details that are useful in characterizing the ship.

The hull

The curved bow and stern are more or less identical, and it thus seems evident that the vessel is double-ended. The hull's most prominent feature is the planking, showing four board 
planks that seem to be joined together near the ends, continuing their lines up to the stem top. The joints are most clear in the bow. The aft third of the ship's side is decorated with crisscross lines. The criss-cross lines do not appear to be structural and could represent decoration of this part of the boat. Evidence for decoration of this type on Viking ship timbers, for instance, has been noted in a Norwegian boat burial at Grønhaug, Karmøy, where a triangular pattern is incised in the board planks and painted black (Shetelig, 1902: 12). It is known from the Gokstad ship burial too (Christensen, 1979: 145-149). The plank lines and joints, however, merit further consideration and while joints are not placed in a recognizable system, they probably are the artist's interpretation of the so-called 'stepped stem' that is known on several Scandinavian Viking Age vessels, particularly from Denmark.

\section{The stem}

On this type of stem the plank ends are fastened at steps cut into the one-piece stem (Fig. 5). The lines of the planks are continued, carved into the sides of the stem, thus creating the impression that the clinker planking continues towards the stem top. This is a common feature of Scandinavian ships and an aesthetically striking feature. The best example can be seen in the fully preserved stem on the Skuldelev wreck 3 (Fig. 5a) from the Isle of Zealand, Denmark (Crumlin-Pedersen and Olsen, 2002: 201-202). This vessel, dated to c.AD 1040, is a small cargo carrier. Stepped stems were also present on Skuldelev wrecks 2 and 5, both of which that both are personnel carriers (Crumlin-Pedersen and Olsen, 2002: 149, 251). Skuldelev wreck 2 is of particular interest because dendrochronological analysis indicates that the ship was built of timber felled around AD 1042, somewhere in the eastern coastal region of Ireland, probably in the Dublin area (Crumlin-Pedersen and Olsen, 2002: 185). Similar stepped stems have been found in Scotland and Ireland: two stepped stems were found in a bog on the Scottish isle of Eigg (Shetelig, 1940: 179-180; Crumlin-Pedersen and Olsen, 2002: 231-232); two stem fragments were excavated in Fishamble Street in Dublin (McGrail, 1993: 146-147); and a single fragment of a stem is known from Waterford (McGrail, 1997: 638). The stems from Dublin and Waterford are found together with several other ship fragments manufactured in the Scandinavian tradition. One of the Eigg stems is ${ }^{14} \mathrm{C}$-dated to cal. AD 870-1150 2 $\sigma$ (Atkinson, 2008, 282). Although the Dublin timbers, where dendrochronological analysis exists, seem to be of Irish origin, the boat fragments were produced by craftsmen evidently working in the Scandinavian shipbuilding tradition (cf. McGrail, 1993: 83; 1997: 636), and the same conclusion applies for the Skuldelev wreck 2 (Crumlin-Pedersen and Olsen, 2002: 186).

\section{Mast and rigging}


The mast is placed amidships and is supported by a forestay, possibly doubled, and what seems to be a backstay or halyard. As mentioned above, it is the forestay that indicates which end is fore. Shrouds are not present. The masthead is characterized by what might be described as an expansion. Most likely this is a thickened part of the mast providing a base for the shrouds and stays as well as strengthening the mast at the halyard hole, similar to the feature on the smaller ship graffito from Winetavern Street in Dublin (Fig. 6a; cf. Christensen, 1988: 16). An alternative explanation, however, that should not be overlooked, is that the masthead feature had a representational meaning. This detail is well-known from Scandinavian rune and picture stones, but also Hedeby coins (cf. Moesgaard and Kastholm, 2014), where the masthead is decorated with crosses, wind vanes or more indefinite structures. These structures might be seen as marks denoting a leading ship, just as the flagship of Duke William is clearly marked with a lantern on the masthead on the Bayeux Tapestry (Scene 38; cf. Rud, 1996: 66). Whether the expansion on the Kilclief masthead has a representational meaning or serves a practical purpose cannot be ascertained.

The sail

The sail is furled under a yard that is almost the same length as the ship itself. The yard is lowered leaving the sail at the same height as the stems. As it is furled, it is not possible to ascertain any detailed information about the sail, except for the rudimentary fact that it is a square sail. The ship with a lowered and furled sail is a common motif in Viking Age Scandinavia, seen for instance in the 10th-century ship graffito from Gauldalen in Norway (Fig. 7d) as well as an engraving in a 9th-century whetstone from Löddeköpinge in Sweden (Alsvik, 1973; Ohlsson, 1976) and denotes a vessel that is moored or at anchor. This motif of the furled square sail, however, is not a particularly diagnostic feature, as it is also occurs on ship depictions from later periods in north-west Europe.

\section{Contextualization of the Kilclief ship}

The engraved ship on the Kilclief stone is a double-ended plank-built vessel fitted with a single square sail. The sail is furled under the lowered yard, indicating a moored ship. The engraving is very detailed but does not show features such as crew, weaponry, oars, or rudder. The stems, however, are drawn in a characteristic way, presumably depicting 'stepped stems'. This type of stem is known from Ireland and Scotland, and is part of a Scandinavian boatbuilding tradition, most notably encountered in the Irish-built longship Skuldelev wreck 2, that ended its days in Danish waters in the late 11th century.

The Kilclief ship is an addition to a small group of insular ship depictions that traditionally are accepted as depicting Scandinavian vessels. The most significant depictions 
are from Dublin, two pieces from Winetavern Street and one from Christchurch Place (Christensen, 1988) (Fig. 6). A few others are known from Jarlshof, Shetland (O’Meadhra, 1993: 427-430, fig. 27.2). A very rudimentary sketch from Chapel Knowe, Orkney might be considered as Scandinavian, too (O’Meadhra, 1993: fig. 27.1), but it does not depict any diagnostic details. Five boats and ship graffiti are known from the Inchmarnock Monastery, Bute. According to Atkinson (2008, 281-282, fig. A3.1: IS.46) one of these, known as the 'Hostage Stone', might show similarities with Scandinavian vessels as it displays a row of several oars and a possible square sail with diagonal hatching. These features, however, can be found on many ship types and the characteristic prows of Scandinavian ships are missing. Another ship depiction from Inchmarnock (Fig. 6c) depicts a double-ended vessel with a single-square-sail rig, and is interpreted as depicting a Western Highlands and Argyll galley (bírlinn) (Atkinson, 2008: 278-279, fig. A3.1: IS.30).

A considerable number of depictions of square-rigged ships are known from Viking Age and Early Medieval Scandinavia (c.AD 750-1200) (for example Varenius, 1992; Kastholm, 2009). Most notably these are found on the many picture stones known from the Isle of Gotland in the Baltic (cf. Lindqvist, 1941: 42), but they also occur on rune stones, textiles, coins, and as graffiti on rock surfaces and church walls. With the exception of some coins from the Hedeby, which can be dated to the 820s, the Scandinavian ship depictions are not precisely dated, each having a date range of a century or more. A selection of these are shown in Figure 7 and it is clear that the Kilclief ship forms part of the same shipbuilding tradition.

\section{Decorative motifs}

The Kilclief stone displays five separate decorative motifs. There are two crude renderings of interlace, a rather rudimentary circular knotwork motif and two zoomorphic figures (Fig. 4). Rudimentary and unsuccessful attempts at interlace are a consistent feature of Irish motif pieces, but this tends to be single line rather than the double line noted at Kilclief. Poor quality double lined attempts, however, have been noted at Lagore, Co. Meath (O’Meadhra, 1979, Cat. No. 127B1), Gransha, Co. Down (O’Meadhra, 1979, Cat. No. 97A1) and High Street Dublin (O’Meadhra, 1979, Cat No. 39B3). Similar work is also present on a trial piece from Dunadd, Scotland (Lane and Campbell, 2000: 198). The closest parallel, however, is the interlace inscribed on the side of a wooden box (Fig. 8) from the Viking settlement Christchurch Place, Dublin, which was found in a context containing a coin of 1055-1075 (Lang, 1988: 55, DW17). It is more difficult to find a parallel for the knotwork motif and it is difficult to ascertain what the carver was endeavouring to achieve in this rather amateur piece 
of work. It is vaguely reminiscent of the decoration on one of the Scandinavian influenced Orcadian Skaill brooch terminals (Graham-Campbell, 1995: 110) or the weavers comb from Viking Fishamble St., Dublin (Lang, 1988: 11). Perhaps a better parallel is the knotwork design on a motif piece from the Scottish Dalriadic site of Dunadd (Fig. 9), which some argue 'shows Scandinavian influence and dates to around the 10th-11th century' (Lane and Campbell, 2000: 186). This is consistent with the date of the Dublin wooden box. It is the interesting to note that the stone type on which it is carved is dissimilar to any of the other stone objects found at Dunadd and could not have been brought to the locality by glacial action (Lane and Campbell, 2000: 186). It is of a metamorphosed mudstone type found in Southern Scotland, the Isle of Man and Co. Down, that is a stone type similar to the Kilclief stone.

The first zoomorphic figure consists of a bird's head attached by a long curving neck to a rectangular shape that appears to be a sitting mammal body with two legs extending at the front. A second neck appears to extend from the first terminating in another head, which for the most part has been broken away. As in the case of the other motifs, the figure is carved in a very basic and unskilled way. Stylized animal heads appear on some motif pieces and related objects. The birds on these, however, display curved or rounded beaks as in the depiction on a tubular piece of bone from the nearby monastic site of Nendrum (Bourke, 2007: 414-415; O’Meadhra, 1979, Cat No. 147A1), or two birds carved on a stone motif piece from Garranes, Co. Cork (O’Kelly, 1963, pl. XII; O’Meadhra, 1979: Cat. No. 69B2). The straight beaks and exaggerated eyes are not present elsewhere in the Irish repertoire. The depiction is, however, similar to the series of beaked 'birdmen' present in Scottish early medieval stone sculpture (Kilpatrick, 2011). They have beaked heads, human bodies and occasionally bird's feet and are depicted carrying a weapon, usually an axe.

The most widely known composite avian animal of the ancient world was the griffin, which had the body of a lion and head of an eagle. With its origins in Mesopotamia, its role developed from guardian beasts to one where the 9th-century Irish John Scottus Erigena regarded the griffin as a model for male chastity (Armour, 1995: 72-73, 89). Winged griffins are depicted on the base of the cross of the scriptures at Clonmacnoise, Co. Offaly (Harbison, 1992: 52, fig 145), on the head of cross at Duleek, Co. Louth (Harbison, 1992: 77, fig. 242) and possibly on one of the figures from White Island, Co. Fermanagh (Moss, 2014: 317). Immediately below the ship is a curvilinear carving that could be interpreted as a stylized seasnake or sea-serpent.

\section{Discussion}


The Kilclief stone is unique in that it combines ship graffiti with decorative elements of the motif piece. The interlace and knotwork o the stone can be related to the training craftworkers in design. In some cases, highly accomplished pieces of design appear on the same piece as unskilled attempts (O’Meadhra, 1979: PN) implying the training of apprentices by means of copying accomplished work. Motif pieces have been found on two sites in the Strangford Lough area. Five pieces were found at the monastic site of Nendrum (Bourke, 2007) while 39 were found at the secular raised rath at Gransha (O’Meadhra, 1979: 72-85; Lynn, 1985), which McErlean et al. (2002, 77) have suggested was a site associated with the major monastic foundation at Bangor.

As a large quantity of stone was ploughed up at the time of discovery, it is possible that the stone originally formed part of a building. Ships were often inscribed in the plasterwork of later medieval churches in Ireland (Brady and Corlett, 2007), and Moss (2014, 93) argues that these were votive images inscribed as a means 'of asking for or offering thanks, for safe passage on a journey'. On balance it would seem that the stone is part of a church building that had been disturbed during ploughing, and it could be suggested that the carvings was carved as a focus for prayer for the safe return of absent mariners or as thanks for their safe return. The placing of carvings or models of ships in churches has a wide distribution, as evidenced by those present in Denmark mentioned above, but also occurred over a long period of time. For example, a silver ship hangs in Notre Dame De Bon Secours in Montreal commemorating the safe return in 1870 of Canadian soldiers who had been defending the Papal State in Italy (Simpson and Pothier, 2001: 106-108).

The question arises as to whether the Kilclief stone was the work of native Irish hand or that of a Scandinavian? There are many problems in raising this question. In the first instance more than one carver may have been involved. The ship, for instance, seems to have been carved with a finer tool than the 'interlace' and some of the other decoration. The intersection of the 'griffin' and 'interlace' with the backstay appears to indicate that the ship was carved before the other decoration. It is not possible, however, to ascertain the temporal interval between the carvings. Secondly, by the 11th century Irish art was so influenced by that of Scandinavia it is difficult to differentiate between the two. That said, the art depicted on the Kilclief stone shows clear parallels with work being produced in Scandinavian Dublin.

The ship is clearly of Scandinavian type, but is quite likely that Irish military ships of the time were also of this type. Halpin $(2010,2015)$ has shown that the Irish quickly adopted Viking ways of conducting warfare, such as the use of the bow and the battle axe. Swift's examination of the documentary evidence indicates that they also adapted Scandinavian ship 
design with much of the terminology used being Old Norse loan words (Swift, 2015, 466467; also Lucas, 1966). It is not certain how early the Irish began building ships in the Scandinavian fashion but the Annals of Ulster record that in 1022 the Ulaidh, the ruling dynasty in the Strangford area, were able to defeat the Scandinavian/Hiberno-Norse of Dublin in 'a naval battle in the open sea' (Hennessy, 1887¹). This could imply Irish ship design had progressed to equal that of the Vikings by this time. Viking-type ships were certainly being built in Ireland in the 11th century as the Skuldelev 2 longship was made of Irish oak felled in 1042.

Swift's study of the Book of Rights (Dillon, 1962), which dates roughly to the latter half of the 11th century, could well provide a context for the ship carving at Kilclief (Swift, 2004). The document lists the gifts that a Munster over-king, based in Cashel, Co. Tipperary, makes to subordinate kingdoms in different parts of Ireland. One of the most important elements of these gifts was longships. Swift (2004: 202) argues that these ships were called on as part of a ship levy when needed, and the system 'was a form of laídeng-the Irish form of the Old Norse leiðangr, which was used to denote ship levy in eleventh-century and later sources in Scandinavia' (Swift, 2015: 468). The leiðangr, however, is not documented in a fully developed form in Scandinavia until the 13th century, and it is not clear if the practice originated in the Viking Age (Lund, 2001: 150-151). It is clear from the document that one of the key aspects of the military stratagem of the Munster over-kings was to gain control of Irish seaways by providing grants of ships to those subordinates that controlled key harbours and whose lands abutted strategic sea routes. On the basis of the number of longships granted, it is clear that the Munster kings regraded the sea between Carlingford Lough and Strangford Lough, the Isle of Man and Galloway in south-west Scotland, as the most important in Ireland, presumably because it lay on the route between Dublin, Scotland and Scandinavia (Swift, 2004: 198). The Ulaidh sub-kingdom of Lecale was granted eight ships by the Munster king: 'Eight slaves, eight women, eight horses and eight ships to the king of Leth Cathail' (Dillon, 1962: 85). Kilclief provides one of the few sheltered bays suitable for mooring on the seaward side of Lecale. Perhaps the carving is a representation of one the longships granted by the King of Munster in the later 11th century deployed at Kilclief.

\section{Acknowledgements}

Finbar McCormick would like to thank William Mulhall for bringing the carved stone to his attention and to Brendan Masterson for allowing him continual access to the stone in its present position; also Uaininn O'Meadhra, Richard Warner and Niamh Whitfield for their 
opinions of the carving and Tony Corey and Liam McQuillan (Department of Environment: Historic Environment Division) for photographing the stone, John Meneely (QUB) for scanning the stone, Libby Mulqueeny (QUB) for providing the drawings for this article; and finally, Pat Wallace for his comments on the text. Ole Kastholm would like to thank the picture archivists at the Viking Ship Museum in Roskilde for their kind assistance.

\section{Note}

1) The years quoted in Hennessy's Annals of Ulster are a year out and have been corrected in this article.

\section{References}

Alsvik, A. S., 1973, Ristninger i Gauldalen. Nicolay 13, 35-39.

Armour, P., 1995, Griffin, in J. Cherry (ed.), Mythical Beasts, London, British Museum Press.

Atkinson, D., 2008, Appendix 3: The Inchmarnock boat and ship graffiti, in C. Lowe, Inchmarnock: An early historic island monastery and its archaeological landscape, 277-283. Deinburgh, Society of Antiquaries of Scotland.

Bourke, C., 2007, The monastery of St Mo-Choí: The early medieval finds, in T. McErlean and N. Crothers, Harnessing the Tides: The Early Medieval Tide Mills at Nendrum Monastery, Strangford Lough, 406-418. Belfast.

Brady, K. and C. Corlett, 2007, Ships on plaster: evidence for ships in medieval Ireland, in C. Manning (ed.) From ringforts to fortified houses: Studies on castles and other monuments in honour of David Sweetman. 309-334 . Wordwell, Bray.

Christensen, A. E., 1979, Gokstadskipets dekorative utstyr. Universitetets Oldsakssamling, Årbok, 145-149.

Christensen, A. E., 1988, Ship graffiti and models, in Miscellanea, Medieval Dublin Excavations 1942-81, Series B. Vol. 2, 13-26. Royal Irish Academy, Dublin.

Crumlin-Pedersen, O. and Olsen, O., 2002, The Skuldelev Ships I. Topography, Archaeology, History, Conservation and Display. Ships and Boats of the North, Vol. 4:1. Roskilde.

Dillon, M., 1962, Lebor ne Cert: the Book of Rights. Dublin, Irish Texts Society, Vol. 46.

Graham-Campbell, J., 1995, The Viking-Age gold and silver of Scotland. Edinburgh, National Museums of Scotland.

Halpin, A., 2010, Weapons and warfare in Viking-Age Ireland, in J. Sheehan and D Ó Corráin (eds), The Viking Age: Ireland and the West, 124-135. Dublin. 
Halpin, A., 2015, The Ballinderry bow: an under-appreciated Viking weapon, in H.B. Clarke and R. Johnson (eds), The Vikings in Ireland and Beyond, 151-160. Dublin.

Harbison, P., 1992, The high crosses of Ireland: An iconographical and photographic survey, Volume 2. Bonn.

Hennessy, W. M., 1887, The Annals of Ulster, Vol. 1. Dublin.

Jope, E. M., 1966, An archaeological survey of County Down. Belfast.

Kastholm, O. T., 2009, De gotlandske billedsten og rekonstruktionen af vikingeskibenes sejl. Aarbøger for Nordisk Oldkyndighed og Historie 2005, 99-159.

Kilpatrick, K. A., 2011, The iconography of the Papil Stone: sculptural and literary comparisons with a Pictish motif. Proceedings of the Royal Society of Antiquaries of Scotland 141, 159-205.

Lane, A. and Campbell, E., 2000, Dunadd: An early Dalriadic capital. Oxford.

Lang, J. T., 1988, Viking-age decorated wood: A study in its ornament and style. Medieval Dublin Excavations 1962-81, Series B, Vol. 1, Dublin, Royal Irish academy.

Lindqvist, S., 1941-1942: Gotlands Bildsteine I-II. Kungl. Vitterhets Historie och Antikvitets Akademien. Stockholm.

Lowe, C., 2008, Inchmarnock: An early historic island monastery and its archaeological landscape, Deinburgh, Society of Antiquaries of Scotland.

Lucas, A. T., 1966, Irish-Norse relationships: time for a re-appraisal? Journal of the Cork Historical an Archaeological Society 71, 62-75.

Lund, N., 2001, Expedicio in Denmark, in R. P. Abels and B. S. Bachrach (eds), The Normans and their adversaries at war. Essays in memory of C. Warren Hollister, 149166. Woodbridge.

Lynn, C. J., 1985, Excavations on a Mound at Gransha, County Down, 1972 and 1982: An Interim Report. Ulster Journal of Archaeology 48, 81-90.

McErlean, T., McConkey, R. and Forsythe, W., 2002, Strangford Lough: An archaeological survey of the maritime cultural landscape. Belfast.

McGrail, S., 1993, Medieval Boat and Ship Timbers from Dublin. Medieval Dublin Excavations 1962-1981. Ser. B 3. Royal Irish Academy. Dublin.

McGrail, S., 1997, The Boat Timbers, in M. F. Hurley, O. B. M. Scully and S. J. McCutcheon (eds), Late Viking Age and Medieval Waterford. Excavations 1986-1992, 636-642. Waterford.

Moesgaard, J. C. and Kastholm, O. T., 2014, Making new money: the Hedeby coin. in S. M. Sindbæk and A. Trakadas (eds), The World in the Viking Age, 102-103. Roskilde. 
Moss, R., 2014, Art and Architecture of Ireland Vol. 1: Medieval c.400-1600. Dublin, Royal Irish Academy

Ohlsson, T., 1976, The Löddeköpinge Investigation I. The Settlement at Vikhögsvägen. Meddelanden från Lunds Universitets Historiska Museum 1975-1976, 59-161. Place of publication

O’Donovan, J., 1856, Annals of the Kingdom of Ireland by the Four Masters, Vol. 2. Dublin.

O’Meadhra, U., 1979, Early Christian, Viking and Romanesque Art: Motif-pieces from Ireland. A descriptive catalogue of so-called 'trial pieces' from 5th-12th centuries $A D$, found in Ireland c.1830-1973. Theses and Papers in North-European Archaeology 17, Stockholm.

O’Meadhra, U., 1993, Viking-age sketches and motif-pieces from the Northern Earldoms, in C. E. Batey, J. Jesch and C. D. Morris (eds.), The Viking Age in Caithness, Orkney and the North Atlantic, 423-440. Edinburgh, Edinburgh University Press.

O’Kelly, M. J., 1963, Two ring-forts at Garryduff, C. Cork. Proceedings of the Royal Irish Academy 63C, 17-125.

Ó’Rian, P., 2011, A Dictionary of Irish Saints. Dublin.

Reeves, W., 1847, Ecclesiastical antiquities of Down, Connor and Dromore. Dublin.

Rud, M., 1996 (2nd edn), The Bayeux Tapestry and the Battle of Hastings 1066. Copenhagen.

Shetelig, H., 1902, En plyndret Baadgrav. Bergen Museums Aarbog, nr. 8, 3-14.

Shetelig, H. (ed.), 1940, Viking antiquities in Great Britain and Ireland. Vol. II. Oslo.

Simpson, P. and Pothier, L., 2001, Notre-Dame-De-Bon-Secours: A chapel and its neighbourhood. Quebec.

Swift, C., 2004, Royal fleets in Viking Ireland: The evidence of Lebor Na Cert, in J. Hines, A. Lane and M. Redknap (eds), Land, sea and home: proceedings of a conference on Viking-period settlement at Cardiff, July 2001, 189-206. The Society of Medieval Archaeology monographs vol. 20, Manley, Leeds.

Swift, C., 2015, Hiberno-Scandinavian military culture in Middle-Irish literature in H. B. Clarke and R. Johnston (eds), The Vikings in Ireland and Beyond 451-469. Four Courts, Dublin.

Varenius, B., 1992, Det nordiska skeppet. Teknologi och samhällsstrategi i vikingatid och medeltid. Stockholm Studies in Archaeology 10.

\section{Captions}


Figure 1. Kilclief, Co. Down, showing approximate find-spot of carved stone. (Libby Mulqueeny?)

Figure 2. Photograph of ship. (C DOENI)

Figure 3. Scan of ship. (John Meneely, QUB)

Figure 4. Kilclief ship drawing. (Libby Mulqueeny?)

Figure 5. a) Stepped-stem from wreck 3 Skuldelev, Roskilde Fjord, Denmark. (@ The Viking Ship Museum in Roskilde); b) Viking ship replicas with stepped-stems at the Viking Ship Museum in Roskilde. (Photo Ole Kastholm)

Figure 6. Graffiti of Scandinavian-type ships from a) Winetavern Street Dublin; b) Christ Church Place, Dublin; and c) Inchmarnock. (After Christensen, 1988: 14, fig. 2, 17, fig. 3 : Lowe, 2008: 162, fig. 6:29 , Libby Mulqueeny?)

Figure 7. A selection of Scandinavian ship depictions: a) ship on rune stone from Sparlösa, Sweden, 9th century; b) ship motif on Hedeby coin c.AD 825; $c$ ) ship from Gotlandic picture stone, Klinte Hunninge, 9th-10th century; e) graffito from Gauldalen, Norway, 10th century; f) and $g$ ) graffiti from medieval church in Himmelev, Denmark, early 12th century.

(Drawings by Ole Kastholm)

Figure 8. Interlace on wooden box from Christchurch Place, Dublin (after Lang, 1998: 55, fig. 65, Libby Mulqueeny?)

Figure 9. Knotwork design from Dunadd, Argyll, Scotland (Lane and Campbell, 2000: 186, fig. 4:97, Libby Mulqueeny?) 